\title{
Effects of Beech and Japanese Cedar Trees on Acid Precipitation
}

\author{
Katsuhiro Kikuchi, Noboru Katano and Yoshiaki Sasaki \\ Department of Biological Environment, Faculty of Bioresource Sciences, \\ Akita Prefectural University, Akita, 010-0195, Japan
}

\begin{abstract}
To clarify the impact of acid precipitation on the trees in the buffer zone and adjacent areas in the Shirakami-Sanchi World Natural Heritage Area, the effect of beech trees and Japanese cedar trees on acid precipitation was examined. Through these observations and experiments, it was clarified that throughfall and stemflow of beech trees and Japanese cedar trees can neutralize acid rain. We assume that potassium ions in the leaves and needles of these trees are able to neutralize the acidic substances in raindrops falling on the leaves and needles.
\end{abstract}

Keywords: Acid precipitation, Beech, Japanese cedar, Neutralization, Shirakami-Sanchi World Heritage Area

\section{Introduction}

Acid precipitation is an important aspect of conservation of the global environment. The effects of such acid precipitation on the forest ecosystem of Japan have fortunately not been realized until recently. However, it is clear that the ecosystem will be detrimentally influenced by the continued accumulation of these acidic substances. To address this situation in Japan, studies on the effect of acid precipitation on forest ecosystems have been continued (Kawanabe, 1999a,b; Satake, 2000; Satake, 2001a,b,c).

The Shirakami-Sanchi (mountain range) World Natural Heritage Area is located along the east to west border of the two prefectures of Akita and Aomori in the Tohoku (northeastern) district of Japan. The area is characterized by a primeval forest of beech trees (Fagus crenata Blume (Fagaceae)), by heavy snowfall brought by northwesterly monsoon winds in the winter season, and by heavy rainfall in the summer season. At the foot of the mountains and the plains of Akita Prefecture, the Japanese cedar (Cryptomeria japonica (L.fil) D. Don.) is the most common tree and has been designated as the tree of Akita Prefecture, Japan.

To evaluate the impact of acid rain on the buffer zone of the Heritage Area, we have conducted comparative observations of rainfall, as well as throughfall and stemflow in beech trees and Japanese cedar trees. 


\section{Observation sites}

Three observation sites were selected as shown in Fig. 1; the first is Anmon (star mark A: A-site) in the buffer zone inside Aomori Prefecture; the second is Futatsu-mori (star mark F: F-site) in the buffer zone inside Akita Prefecture; and also is Dakedai (star mark D: D-site) Natural Educational Forest which is typified by beech trees outside the buffer zone in Akita Prefecture.

At the D-site, for instance, a MAWS (Mobile Automatic

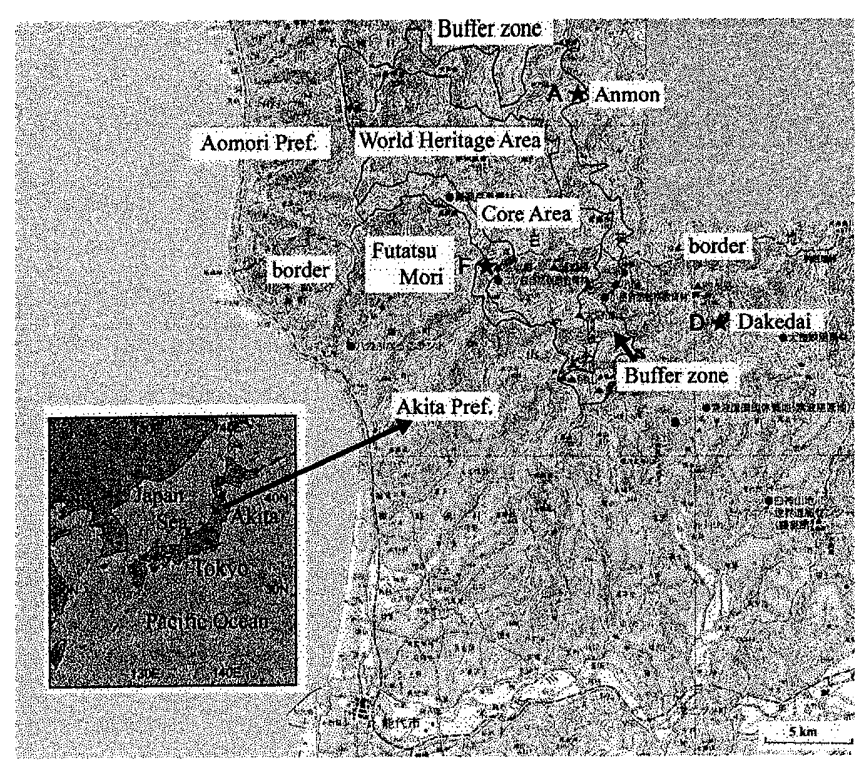

Fig. 1 Map around the Shirakami-Sanchi Mountain Area

Weather Station for meteorological observation) system and a rain water bucket were employed in the open space within the beech forest. With this system, it was possible to obtain opening rainfall data in the open space. In addition, the same system was used to collect throughfall, and also stemflow in a big plastic bag surrounding the trunk of sample beech and Japanese cedar trees. It was, therefore, possible to collect throughfall and stemflow data within the beech forest in the forest space. Here, we define opening rainfall, throughfall and stemflow as follows. Opening rainfall refers to real rainfall in which the raindrops do not come into contact with any beech leaves or branches; the throughfall refers to falling raindrops that come into contact with leaves, twigs and branches; and stemflow refers to raindrops that flow down the tree trunk. The diameter of breast height $(\mathrm{DBH})$ and height of the sampled beech and Japanese cedar trees at the D-site were $35 \mathrm{~cm}$ and shorter than $25 \mathrm{~m}$ to beech, and $25 \mathrm{~cm}$ and shorter than $20 \mathrm{~m}$ to Japanese cedar trees, respectively. Therefore, we were able to conduct comparative observations of rainfall outside the forest, as well as throughfall and stemflow of beech trees and Japanese cedar trees. Sampled water collected at each site was refilled into plastic bottles and taken to our laboratory. After the arrival at our laboratory, their $\mathrm{pH}$ values were measured by METTLER MP230 Type $\mathrm{pH}$ meter and a couple of days later, main ion concentrations were measured by an ion chromatograph (Dionex DX-120) at the Akita Prefectural Institute of Environment. Field experiments were conducted in the first 10 days of September at the D-site (Dakedai), the last 10 days of September at the 


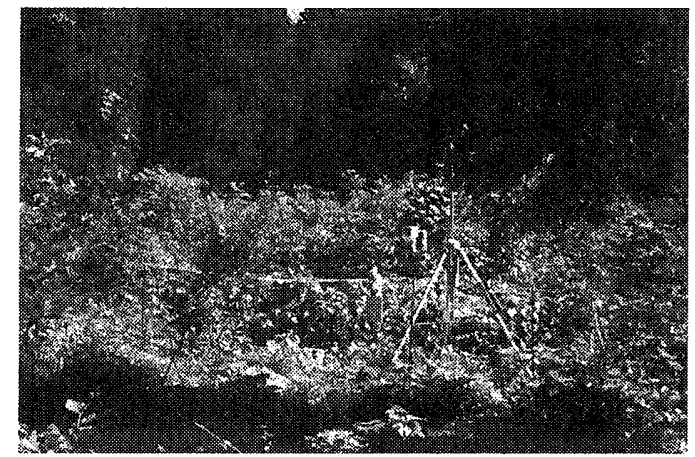

(a)

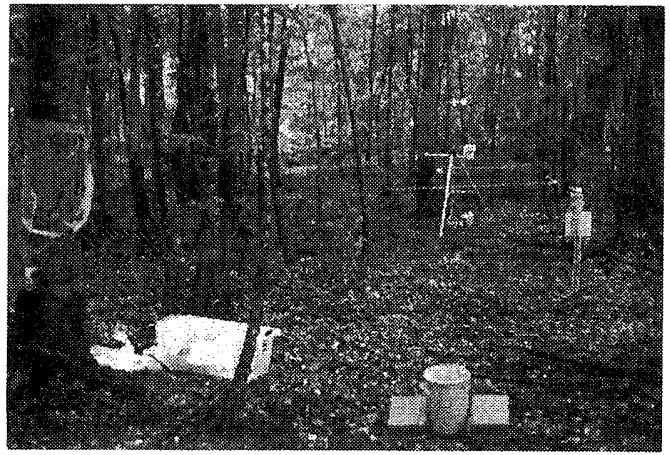

(b)

Fig. 2 (a) Opening site, (b) Throughfall and stemflow site at Dakedai.

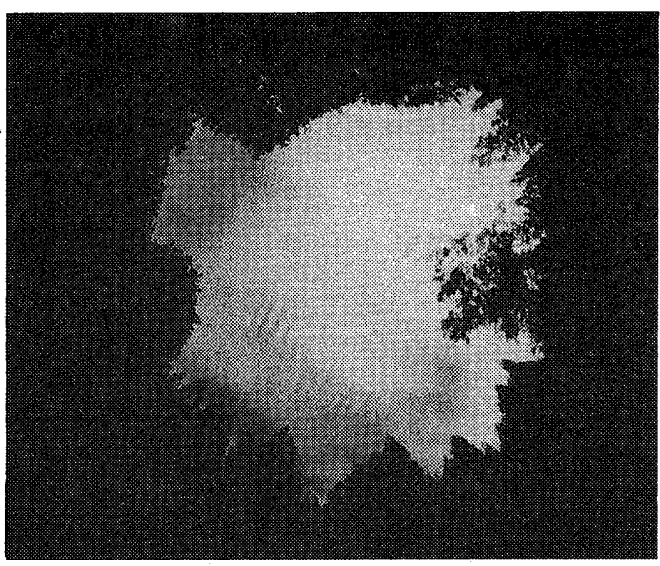

(a)

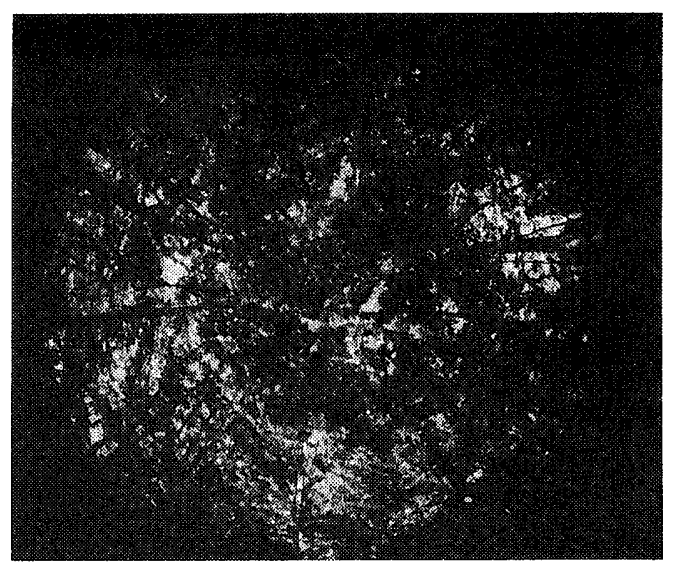

(b)

Fig. 3 (a) Whole sky pictures at (a) Opening site, (b) Throughfall site at Dakedai

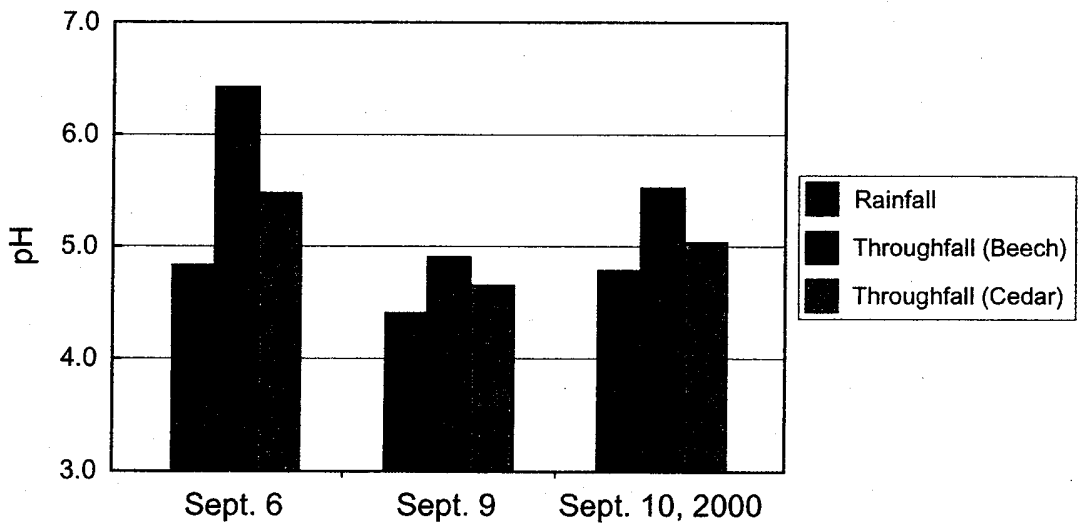

Fig. $4 \mathrm{pH}$ values of opening rainfalls and throughfalls of Beech and Cedar trees 
A-site (Anmon), the last 10 days of October at the F-site (Futatsu-mori), and over several days in November at the D-site, 2000. Figures 2 (a) and (b) show scenes of open space and forest space, respectively. Figures 3 (a) and (b) show whole sky pictures pointing upwards at the opening site and the throughfall site, respectively. At this time, a canopy openness of the throughfall site was less than $10 \%$.

\section{Observations of rainfall, throughfall and stemflow at the $D$-site}

Figure 4 shows the $\mathrm{pH}$ values of the opening rainfall and throughfall of beech and Japanese cedar trees. As seen clearly, the $\mathrm{pH}$ values of throughfall were higher than those of opening rainfall. These results show the same tendency as beech trees obtained by Inoue et al., (1993). Thus, $\mathrm{pH}$ values of throughfall of Japanese cedar tree were higher than those of opening rainfall, but were lower than those of throughfall of beech tree. These results show the same tendency as beech trees, but the opposite to that of Japanese cedar observed previously (Sassa et al., 1991). To clarify this discrepancy between beech and Japanese cedar in these two studies, we selected more trees for both species. Figure 5 shows the $\mathrm{pH}$ values and ion concentrations of opening rainfall and throughfall at the D-site on September 9, 2000. In this case, one additional beech and Japanese cedar tree were each selected as sample trees (Beech 2 and Cedar 2). As seen in this figure, the $\mathrm{pH}$ values of beech 1 and 2, and cedar 1 and 2 were nearly equivalent, whereas the total ion concentrations in $\mathrm{mg} / \mathrm{l}$ in opening rainfall and throughfall of beech and cedar trees showed particular differences.

It is noteworthy that there were hardly any potassium ions identified in the rainfall, whereas there were high potassium ion concentrations in all throughfalls of both beech and Japanese cedar trees as seen in the figure. To reconfirm that potassium ions were not present in opening rainfall, two more sampling buckets were used to collect opening rainfall near the opening rainfall site. Figure 6 shows one example of the experiments performed on September 10, 2000. As in the previous example, shown in Fig. 5, potassium ion levels were very low in all three sampling buckets at the opening rainfall site, but occurred at high levels in samples of throughfalls of beech and Japanese cedar trees. Figure 7 shows one example of the time variations of $\mathrm{pH}$ values and ion concentrations of stemflow of the beech-1 tree. In these measurements of stemflow, sampling was performed every 0.1 litres of stemflow. These analyses are most probably the first time that such detailed measurements of $\mathrm{pH}$ and ion concentrations of stemflow on beech trees have been conducted in connection with acid rain. In this figure, the vertical axis represents the $\mathrm{pH}$ value or ion concentrations in $\mathrm{mg} / \mathrm{l}$, and the horizontal axis represents the irregular time scale. The time variations in $\mathrm{K}, \mathrm{NO}_{3}$ and $\mathrm{SO}_{4}$ ion concentrations were large compared with changes in the other ions. These $\mathrm{K}, \mathrm{NO}_{3}$ and $\mathrm{SO}_{4}$ 

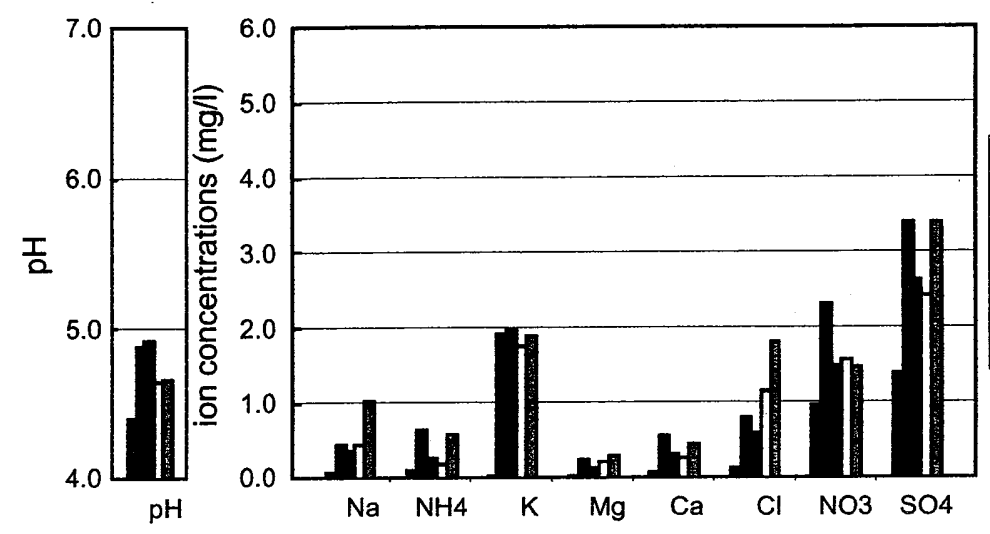

\begin{tabular}{|l}
\hline Rainfall \\
Throughfall (Beech 1) \\
Throughfall (Beech 2) \\
$\square$ Throughfall (Cedar 1) \\
Throughfall (Cedar 2)
\end{tabular}

Fig. $5 \mathrm{pH}$ values and ion concentrations $(\mathrm{mg} / \mathrm{l})$ of opening rainfalls and throughfalls at Dakedai Educational Forest
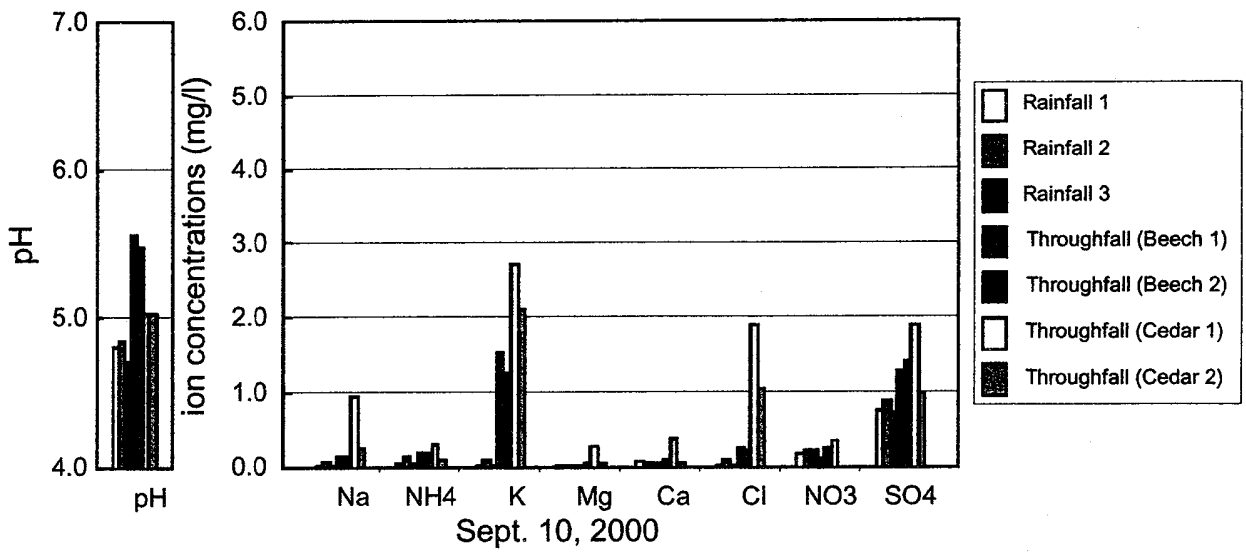

Fig. $6 \mathrm{pH}$ values and ion concentrations $(\mathrm{mg} / \mathrm{l})$ of opening rainfalls and

throughfalls at Dakedai Educational Forest

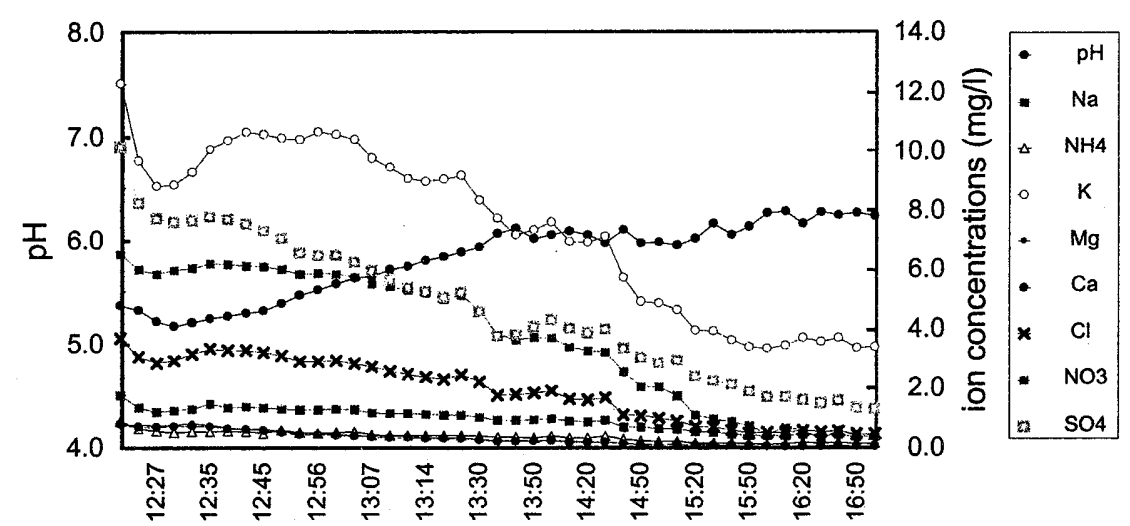

Sept. 9, 2000

Fig. $7 \mathrm{pH}$ values and ion concentrations $(\mathrm{mg} / \mathrm{l})$ of stemflow $($ Beech -1$)$ 


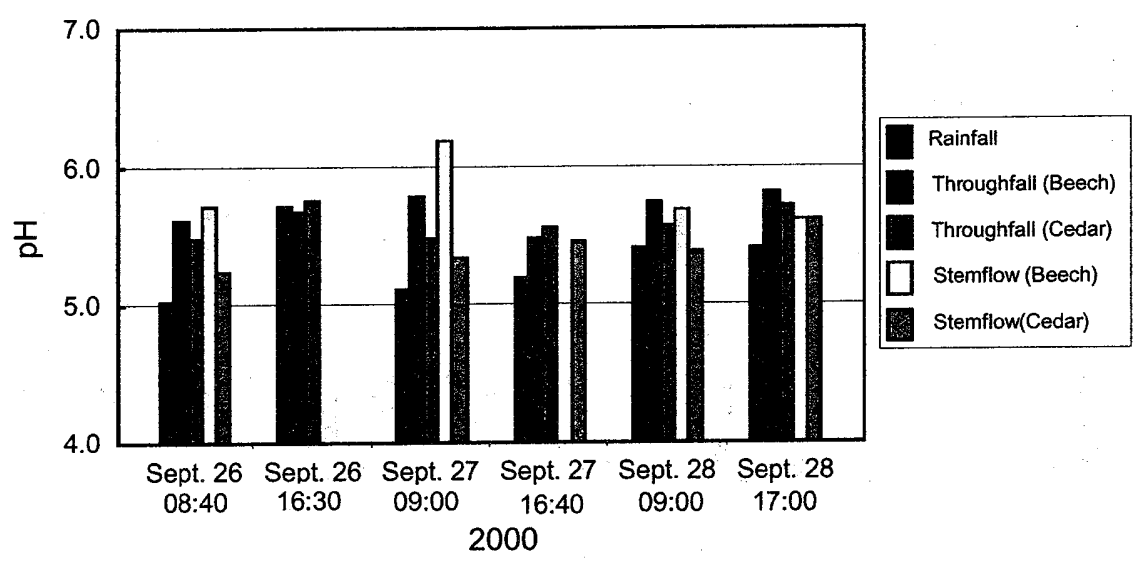

Fig. $8 \mathrm{pH}$ values of opening rainfalls, throughfalls and stemflows at the Buffer zone around Anmon-no-taki

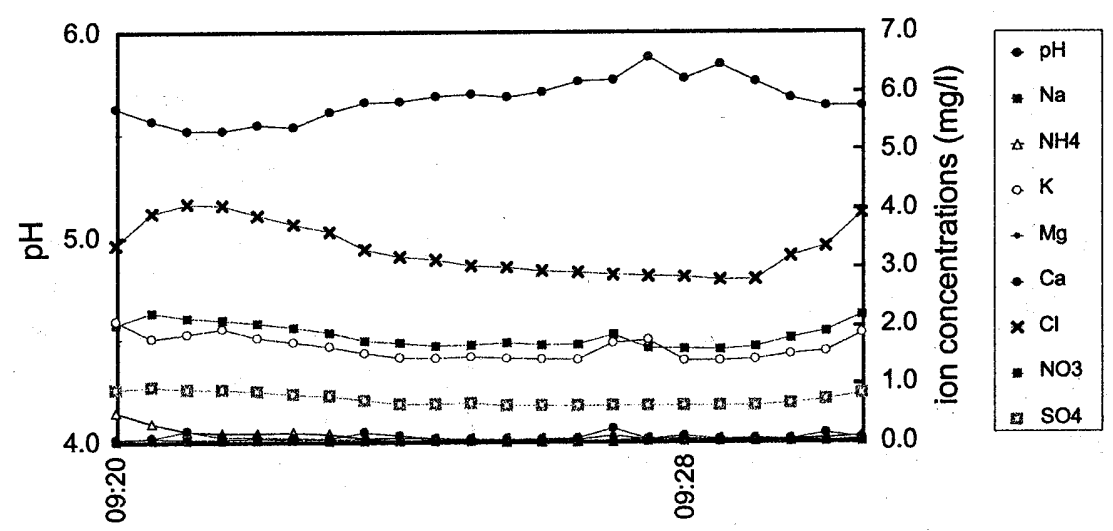

Sept. 26,2000

Fig. $9 \mathrm{pH}$ values and ion concentrations (mg/l) of stemflows of Beech tree at the Buffer zone around Anmon-no-taki

ions decreased continuously from the start of stemflow measurements to the end, however, the $\mathrm{K}$ ion still remained at relatively higher levels.

\section{Observations at the $A$-site and F-site in the buffer zone}

Subsequently, observations were conducted at Anmon, at the entrance of the buffer zone in Aomori Prefecture, and were obtained results shown in Figure 8. At this site, samples of rainfall were collected twice per day. During the observation period, $\mathrm{pH}$ values were 5.0 or more, and were higher than those at the $\mathrm{D}$-site. $\mathrm{pH}$ values of throughfall and stemflow of beech and Japanese cedar trees were higher than those of opening rainfall in all cases. Furthermore, the $\mathrm{pH}$ values of throughfall and stemflow were generally higher in beech trees 
than in Japanese cedar trees. Time variations in $\mathrm{pH}$ values and ion concentrations of stemflows of beech tree on September 26, 2000 are shown in Fig. 9. As seen in this figure, the time variations in $\mathrm{pH}$ values of stemflows were small, most probably reflecting the small variations in $\mathrm{K}, \mathrm{NO}_{3}$ and $\mathrm{SO}_{4}$ ions during the short duration of the experiment. In this case, however, $\mathrm{Na}$ and $\mathrm{Cl}$ ion concentrations were large compared to the other ions. We therefore consider that this rainfall was brought by a westerly wind under the west-high and east-low pressure pattern. In addition, similar observations, in the last 10 days of October, were conducted at Futatsu-mori at the entrance of the buffer zone in the Akita Prefectural side. The results obtained were similar to our previous observations.

\section{Observations at the $D$-site at the start of the winter season}

In three days in November 2000, when almost all beech leaves were defoliated at the mountainous D-site, where it was the start of winter, observations focused on the $\mathrm{pH}$ values of throughfall of defoliated beech trees. The results of throughfall and stemflow of beech trees and throughfall of Japanese cedar trees are presented in Fig.10. The pH values of throughfall and stemflow were generally very similar. At this time, the beech trees were almost completely defoliated, except for a few leaves, so that throughfall in beech refers to precipitation particles that did not touch the leaves but rather only the twigs and branches of the beech tree. Furthermore, during this season in the northern and mountainous regions of Japan, the precipitation types were snow sometimes sleet. It is therefore understandable that the $\mathrm{pH}$ values of precipitation, throughfall and stemflow were of similar value. At this time, the stemflow of beech trees was melted snow, which accumulated as snow and sleet on branches and the trunks. Figure 11 shows the ion concentrations of snowfall as well as throughfall and stemflow. As shown in this figure, the ion contents in snowfall, throughfall, and stemflow were of similar value. Furthermore, there was little difference between throughfalls of beech and cedar trees. In this case, the first snow was brought by northwesterly monsoon winds in this region. As a result, the $\mathrm{Na}$ and $\mathrm{Cl}$ ion concentrations exceeded those of other ions. Similar results were obtained for snowfall on November 11 , 2000. As shown in Fig. 12, the stemflow contained high concentrations of all ion. In comparison with Figs. 5 and 6, it is clear that there is no content of $\mathrm{K}$ ion in the throughfalls of beech and Japanese cedar trees at this time.

\section{Conclusions}

Based on our observations and experiments, we arrive at the following conclusions; (1) Throughfall and stemflow of beech trees and Japanese cedar trees can neutralize acid rain; (2) 


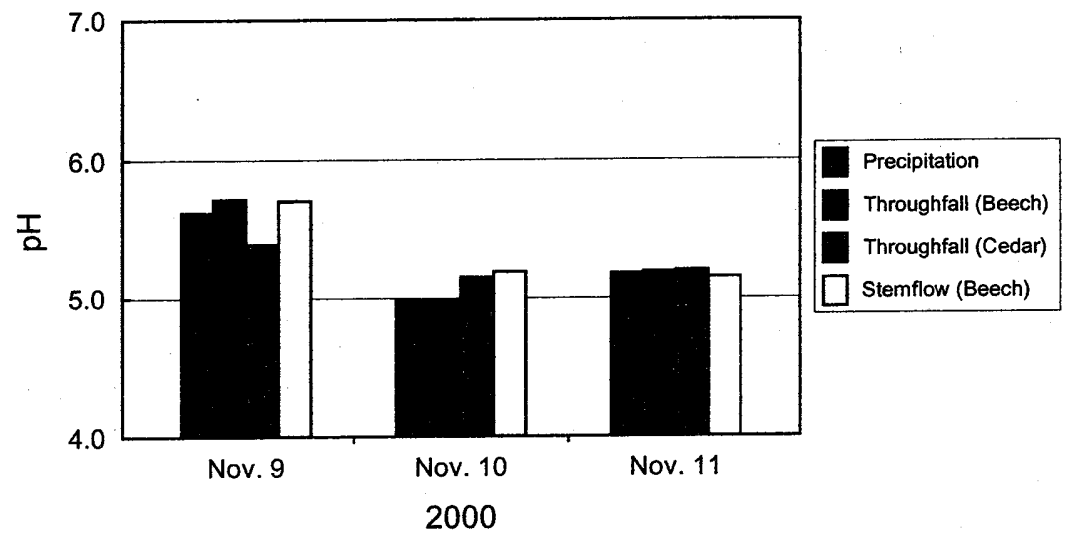

Fig. $10 \mathrm{pH}$ values of precipitation, throughfalls and stemflows at Dakedai Educational

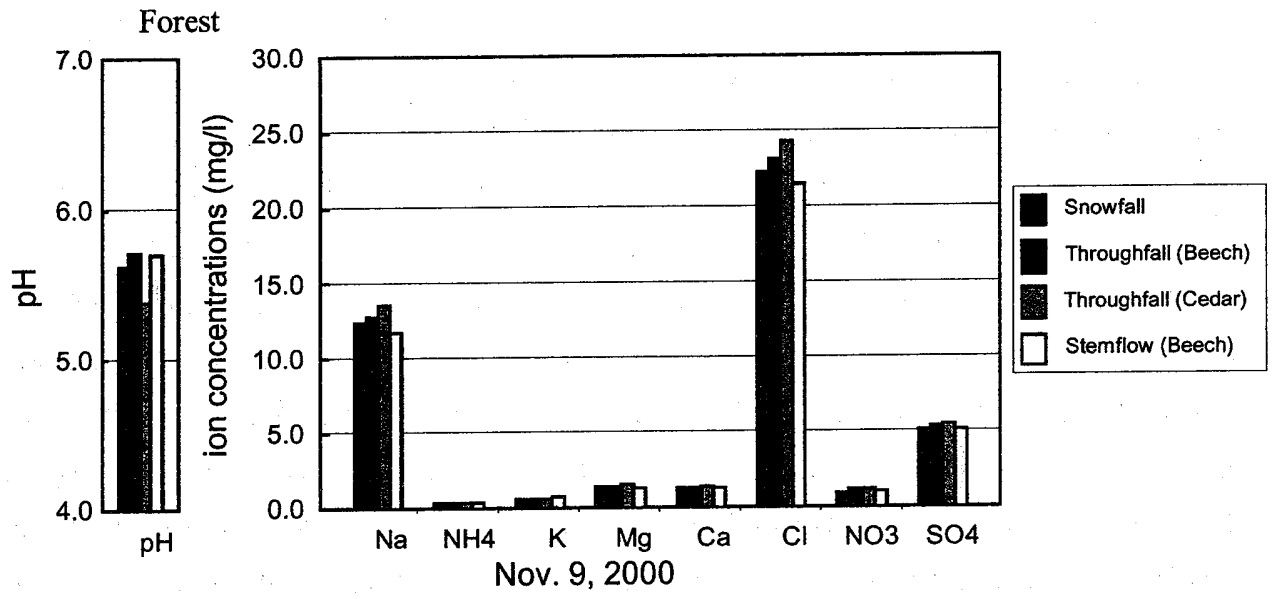

Fig. $11 \mathrm{pH}$ values and ion concentrations ( $\mathrm{mg} / \mathrm{l})$ of snowfall, throughfall and stemflow at Dakedai Educational Forest
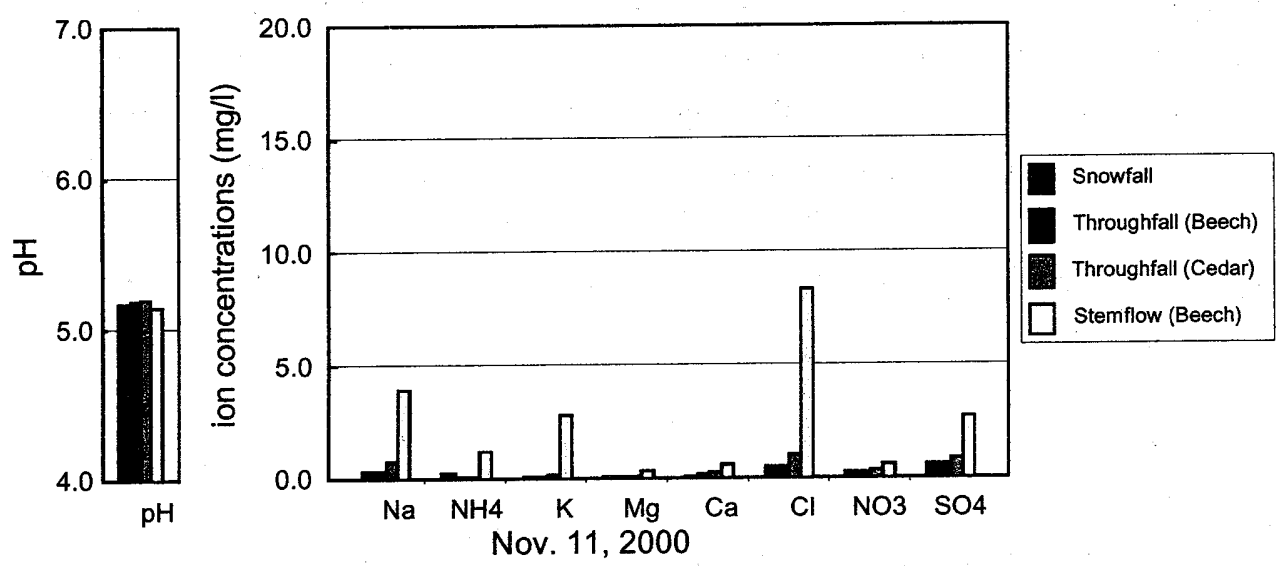

Fig. $12 \mathrm{pH}$ values and ion concentrations (mg/l) of snowfall, throughfall and stemflow at Dakedai Educational Forest 
Neutralization of acid rain by throughfall is more effective than by stemflow in beech trees; (3) The neutralization effects of throughfall and stemflow on acid rain are greater in beech trees than in Japanese cedar trees; and (4) $\mathrm{pH}$ values of throughfall in defoliated beech trees are nearly equivalent to the $\mathrm{pH}$ value of precipitation.

We therefore conclude that beech leaves can effectively neutralize acid rain. Fortunately, beech trees and Japanese cedar trees in the World Natural Heritage Area in Akita and Aomori Prefectures do not appear to manifest any acid precipitation induced damage. Presumably, the potassium ions in leaves and needles of these trees are able to neutralize the acidic depositions from raindrops.

Acknowledgement: We would like to express our hearty thanks to Yoneshiro-Seibu District Forest Office and Tsugaru District Forest Office, Tohoku Regional Forest Office, The Ministry of Agriculture, Forestry and Fisheries. They gave us permission to observe the acid precipitation in the national forest. This research was supported by the Sumitomo-Found (No. 993133: Studies on the Atmospheric, Hydrospheric and Soil Environment Supporting the Biodiversity in the Shirakami Mountain Range by Dr. Katsuhiro Kikuchi, Professor of Akita Prefectural University) and Special Fund of Akita Prefectural University.

\section{References}

Inoue, K., N. Yokota, H. Murai, N. Kumagai and J. Mochizuki, 1993: Rain and percolation waters of beech and Japanese cypress forests in the foot of Mt. Fuji and neutralization of acid rain by a beech tree. Jpn. J. Soil Sci. Plant Nutr., 64, 265-274 (in Japanese with English abstract).

Kawanabe, S. (Ed.), 1999a, b: Wide range comparison of the outflow of acidic substances in the forest regions. (I), (II). Kyoto Univ., (I), 1-298; (II), 299-552 (in Japanese).

Sassa, T., K. Gotoo, K. Hasegawa and S. Ikeda, 1991: Acidity and nutrient elements of the rainfall, throughfall and stemflow in the typical forests around Morioka city, Iwate Pref. Japan. Japanese Journal of Forest Environment, 32, 43-58 (in Japanese with English abstract).

Satake, K., 2000: Abstract Book, 6th International Conference on Acidic Deposition. Kluwer Academic Publishers, 356pp.

Satake, K., 2001a: Proceedings from the 6th International Conference on Acidic Depositon, Vol. I, Kluwer Academic Publishers, 186pp.

Satake, K., 2001b: ibid, Vol. II, 187-922pp.

Satake, K., 2001c: ibid, Vol. III, 923-1854pp.

(Received May 18, 2004; revised June 19, 2004; accepted June 27, 2004) 